\title{
NUTRIENTS AND CHLOROPHYLL-A DISTRIBUTION OVER THE CONTINENTAL MARGIN BETWEEN CABO FRIO (RJ) AND UBATUBA (SP), SOUTHEASTERN BRAZIL: WINTER OF 2010
}

\author{
TAKANOHASHI, R.A. ${ }^{\text {; }}$ MOSER, G.A. O. ${ }^{1}$; FERNANDES, M.A. ${ }^{1}$; ENRICH-PRAST, A. ${ }^{2}$ \& \\ POLLERY, R.C.G. ${ }^{2}$
}

\begin{abstract}
1. Faculdade de Oceanografia, Rio de Janeiro State University, Rio de Janeiro, RJ, Brazil. 2. Instituto de Biologia, Rio de Janeiro Federal University, Rio de Janeiro, RJ, Brazil.
\end{abstract}

\begin{abstract}
Takanohashi, R. A.; Moser, G.a. O.; Fernandes, M.A.; Enrich-Prast, A.; Pollery, R.C.G. 2014. Nutrients and chlorophyll-a off Rio de Janeiro in winter. Braz. J. Aquat. Sci. Technol. 19(3). elSSN 1983-9057. DOI: 10.14210/ bjast.v19n3. Thirty nine oceanographic stations were conducted off Rio de Janeiro and northern São Paulo states, encompassing Cabo Frio, Guanabara Bay, Sepetiba Bay and Ubatuba in the winter of 2010. Dissolved inorganic nutrients (ammonium, nitrite, nitrate, phosphate and silicate) and chlorophyll-a data were used to investigate biogeochemical and physical processes occurring on the continental shelf. The study area corresponded to a transition zone between two distinct biogeographic regions described in the literature, "Cabo Frio upwelling region (23ㅇ)" and "Continental shelf/ Santos Bight $\left(23^{\circ} \mathrm{S}\right.$ to $\left.29^{\circ} 40^{\prime} \mathrm{S}\right)$ ", with some unique aspects highlighted in this study, as the coastal zone influenced by local estuarine plumes from Guanabara and Sepetiba bays; and areas where the SACW was present on the base of the mixed layer: i. off São Sebastião Island, due to the vertical and horizontal shear of currents with an inshore northwards flow; and ii. off Sepetiba Bay, in the midshelf, due to regeneration processes from the bottom up to the deep chlorophyll maximum.
\end{abstract}

Key words: SACW, Estuarine Plumes, Brazilian Continental Shelf, Deep Chlorophyll Maximum, Guanabara Bay, Sepetiba Bay.

\section{INTRODUCTION}

Patterns of nutrients distribution over the continental margins as well as marine biogeochemical cycles are still challenges (Conkright et al., 2000) These regions constitute transition zones between land and the oceans, with a great supply of dissolved and particulate materials from continental runoff (Nittrouer, 1993), where complex oceanographic processes co-occur in distinct temporal and spatial scales (Arndt et al., 2011).

The role of hydrodynamics should not be ignored: it is a key factor redistributing and introducing new nutrients to the shelf waters, especially in the southeast continental margin of Brazil. Features such as the meandering and eddies of the Brazil Current (Silveira et al., 2000), the intrusion of South Atlantic Central Water (SACW) over the continental shelf and its coastal upwelling (Castro et al., 2006), the dynamics of southernmost coastal low-salinity waters during winter (Stevenson et al., 1998; Souza \& Robinson, 2004), and other less known smaller-scale processes (Pereira et al., 2009) are important to understand the local nutrients availability. In a more local scale, the coastal zone of Rio de Janeiro is influenced by estuarine plumes of Guanabara Bay (Soares, 2005) and Sepetiba Bay (Coelho, 2010). This study aims to correlate the distribution of dissolved inorganic nutrients (ammonium, nitrite, nitrate, phosphate and silicate) and chlorophyll-a, collected in a oceanographic cruise over the continental margin off Rio de Janeiro $(\mathrm{RJ})$ an north of São Paulo (SP), to local hydrodynamics and biogeochemical processes, during austral winter of 2010.

\section{MATERIAL AND METHODS}

In the period from June 26th to July 1 st of 2010 , 39 oceanographic stations were conducted from the coastal zone to the continental slope between Cabo Frio (RJ) and Ubatuba (SP), aboard Brazilian Navy's $\mathrm{NHo}$ Cruzeiro do Sul vessel (Fig. 1). Stations were disposed in four transects perpendicular to the coastline, off Cabo Frio (CF), Guanabara Bay (GB), Sepetiba Bay (SB) and Ubatuba (UB), as well as along the $50 \mathrm{~m}$ depth isobath in the coastal zone. At each station, water column profiling was done with a CTD-Rossete (Seabird SBE $25^{\mathrm{TM}}$ and Niskin ${ }^{\circledR}$ bottles) system. During the cruise, current velocities were measured with an ADCP (75 kHz RDI ${ }^{\mathrm{TM}}$ hull-mounted).

Seawater samples were collected in surface, deep chlorophyll maximum (DCM), above and under the DCM, near-bottom (about 20-50 m above the bottom) and bottom (at $10 \%$ of local depth). The dissolved inorganic nutrients (ammonium, nitrite, nitrate, phosphate and silicate) were analyzed by spectrophotometric methods according to Aminot \& Chaussepied (1983) at Laboratório de Biogeoquímica (Universidade Federal do Rio de Janeiro- UFRJ). 
Chlorophyll a concentration was measured in a routinely calibrated Turner Designs Trilogy fluorometer, following the method proposed by Welschmeyer (1994).

Graphics representation of the studied variables was done using Ocean Data View ${ }^{\mathrm{TM}}$ (v. 4.3), Diva Gridding interpolation (Schlitzer, 2011). Water masses thermohaline limits were identified according to Castro et al. (2006) for Tropical Water (TW) and Antarctic Intermediate Water (AAIW), Silva et al. (1984) for SACW, and Braga \& Niencheski (2006) for Coastal Water (CW). The ADCP data were processed at Laboratório de Oceanografia Geológica (UERJ) with the Common Ocean Data Access System (CODAS) package of routines available from the University of
Hawaii (USA) using Python ${ }^{\mathrm{TM}}$ (v. 2.6.6) and Matlab ${ }^{\mathrm{TM}}$ (v. R2007b) software with an ADCP sensor-alignment correction based on the Bottom Track method (CODAS, 2013). In order to explore the relationships among variables, a principal components analysis (PCA) was applied to the standardized and normalized data (Statistica ${ }^{\mathrm{TM}}$ v. 7 ).

\section{RESULTS}

\section{Thermohaline structure}

The water masses structure is represented in the Temperature $x$ Salinity plot in figure 2 . It presented a typical shape for the southeastern Brazilian conti-

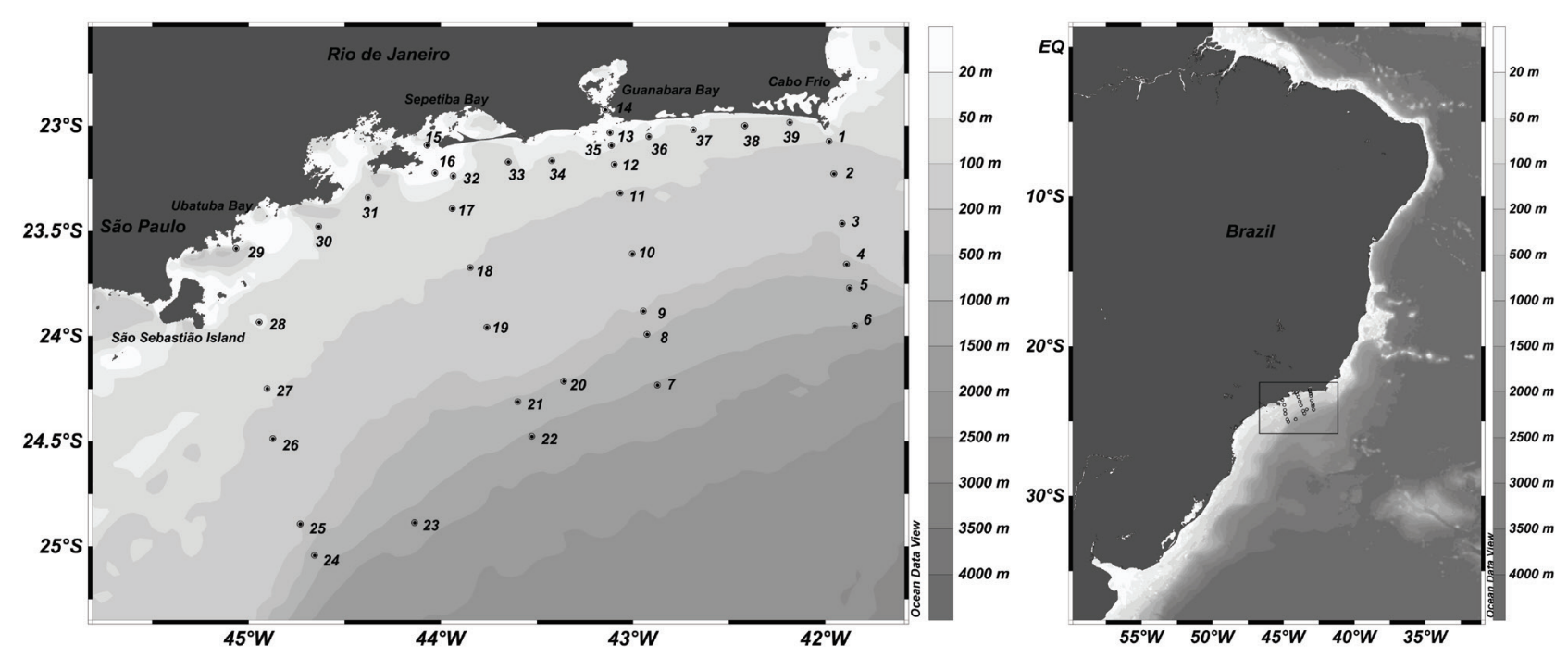

Figure 1: Study area depicting the four transects perpendicular to the coastline, off Cabo Frio (CF; st. 1-6), Guanabara Bay (GB; st. 7-14), Sepetiba Bay (SB; st. 15-22) and Ubatuba (UB; st. 23-29), as well as along the 50m depth isobath in the coastal zone (st. 30-39).

nental shelf (Silva et al., 1984), with TW and CW in the upper layer, the SACW in the pycnocline region, a mixture region between these three water masses and AAIW in deep waters of the continental slope. Surface temperature ranged between $21.9^{\circ} \mathrm{C}$ and $23^{\circ} \mathrm{C}$ (Fig. $3)$, with low values between $\mathrm{CF}$ and $\mathrm{GB}\left(22^{\circ} \mathrm{C}\right.$, st. 37) and off São Sebastião Island (SSI - $21.8^{\circ} \mathrm{C}$, st. 28). Surface TW distribution occurred in an irregular shape, closer to the coastal zone near CF and GB, and limited to slope water in the western section of the study area, as denoted by the 36 isohaline and temperatures above $20^{\circ} \mathrm{C}$ in figure 3 .

At the bottom, temperature ranged between $3.3^{\circ} \mathrm{C}$ and $22^{\circ} \mathrm{C}$, with AAIW over the continental slope from $1013 \mathrm{~m}$ (st. 23) to $1035 \mathrm{~m}$ (st. 22) depth. SACW, bounded by the isotherm of $18^{\circ} \mathrm{C}$, was present in all coastal stations of the along-shore transect, except for station 29, near UB. Its upwelling up to the surface was not verified, and its shallower depth was $32 \mathrm{~m}$, at station 27.

Surface and bottom salinity distribution follows the water masses patterns described above, but it was possible to detect the dominance of waters with salinity lower than 35.5 in the western portion of the study area, from the coastal zone to midshelf waters (Fig. $3)$. The lower salinity value was observed in surface (33) at GB (st. 14), and values of 33.5 were verified inside SB (st. 15). While in GB the low salinity waters influence was limited to the nearest station (35.3, st. $13)$, at SB its influence was registered up to stations 16 (34.8) and 17 (35.2). 


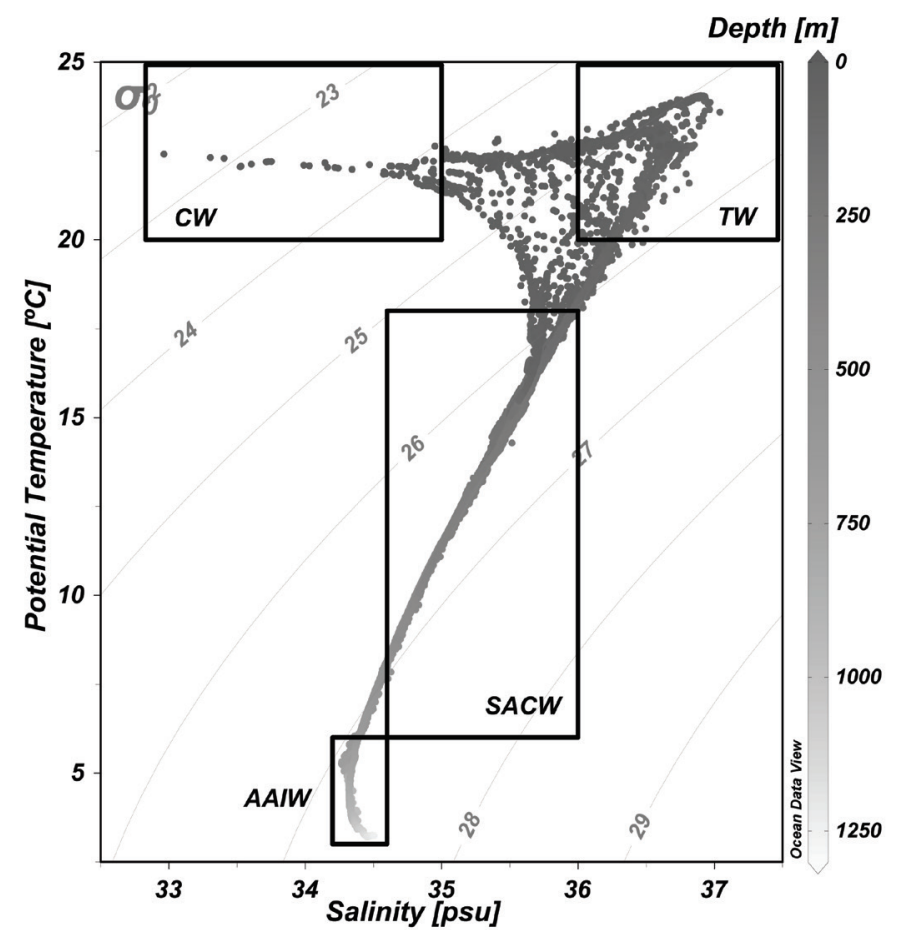

Figure 2: Potential Temperature $x$ Salinity plot with isopycnals represented by thin continuous lines. Depth in water column in grey scale.

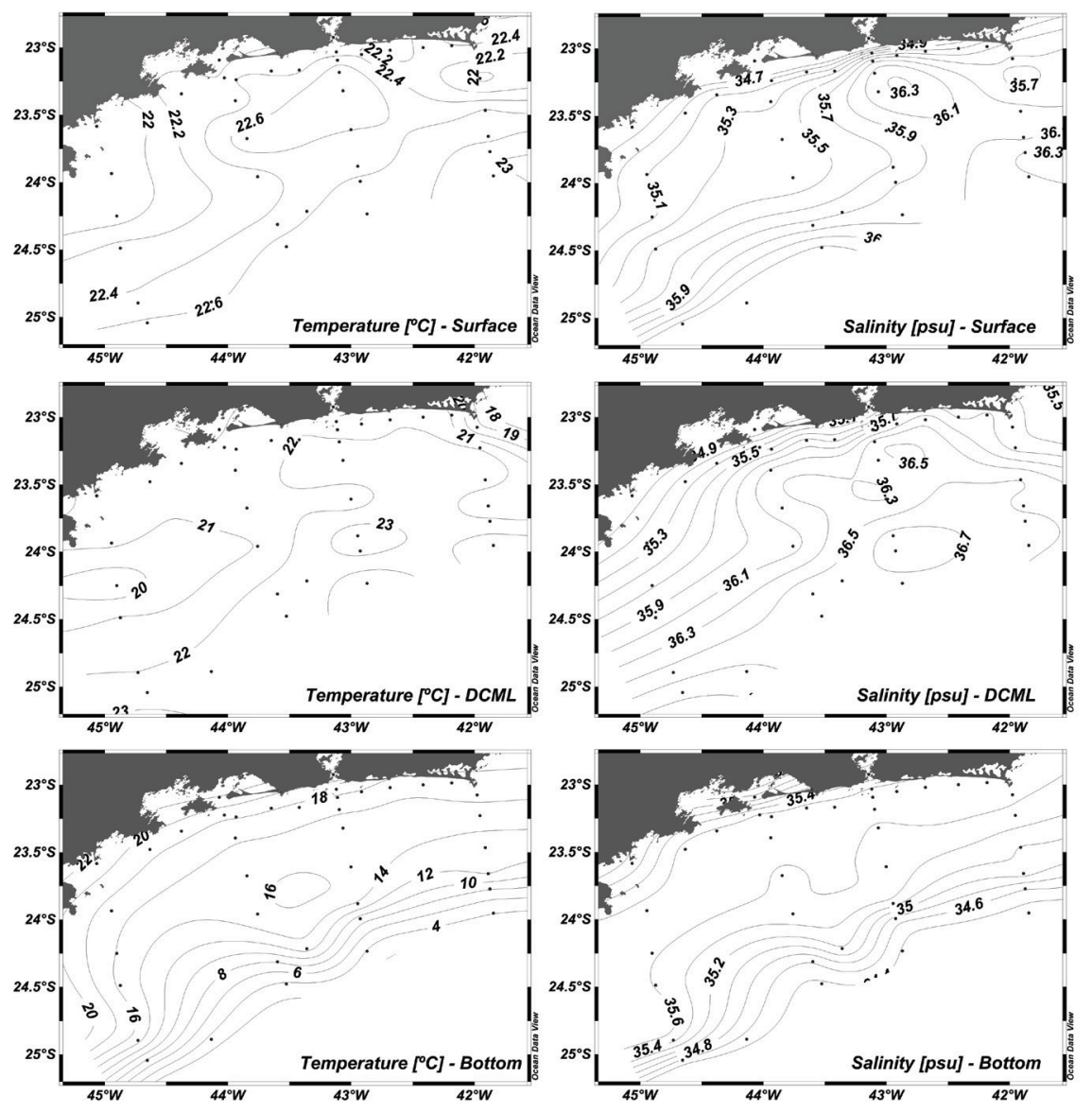

Figure 3: Surface plots of temperature and salinity in Surface, DCM and Bottom. 


\section{Nutrients}

The high ammonium concentrations were detected near the two major coastal bays (Fig. 4), with maximum of $5.5 \mu \mathrm{M}$ inside GB (st. 14) and $0.9 \mu \mathrm{M}$ inside SB (st. 15). Stations 16 and 17 presented $0.8 \mu \mathrm{M}$ and $0.7 \mu \mathrm{M}$, respectively. Ammonium concentrations were very low in most of shelf waters, except in the shelf break off CF (st. 5), where the values increased up to $0.5 \mu \mathrm{M}$ as well as off SSI (st. 27), with $0.4 \mu \mathrm{M}$.

The highest concentration of nitrite was 2.2 $\mu \mathrm{M}$ inside $\mathrm{GB}$ (st. 14), but in the neighboring station it dropped to $0.4 \mu \mathrm{M}$ and then to levels near or below the detection limit $(0,05 \mu \mathrm{M})$ in most of the shelf area (Fig. 4). In SB (st. 15) the lowest value was $0.3 \mu \mathrm{M}$ at $18 \mathrm{~m}$ depth, and concentrations were kept around 0.2 $\mu \mathrm{M}$ in the DCM in stations 16,17 and 18 .
Nitrate presented a well-defined gradient, with lower concentrations at the surface up to values above $30 \mu \mathrm{M}$ associated to the AAIW in the continental slope (Fig.4). At GB (st. 14), it reached $7.3 \mu \mathrm{M}$ at surface, but in SB (st. 15) its concentration was kept below $1 \mu \mathrm{M}$ in the whole water column. In the bottom, two cores of high concentrations were present off SB and off SSI. In the first, at stations 17 and 18, maximum values of $13.3 \mu \mathrm{M}$ and $11.2 \mu \mathrm{M}$ were verified, respectively. Off SSI, values of $9.6 \mu \mathrm{M}$ (st. 28), $10.7 \mu \mathrm{M}$ (st. 27) and $11.3 \mu \mathrm{M}$ (st. 26) were also recorded. The augment of nitrate off SSI extended from the bottom up to the DCM, with $5.5 \mu \mathrm{M}$ (st. 27) at $25 \mathrm{~m}$ depth.

The phosphate also had higher concentrations in the bottom waters (Fig. 5), dominated by SACW and AAIW. Maximum concentration was $3 \mu \mathrm{M}$ over the

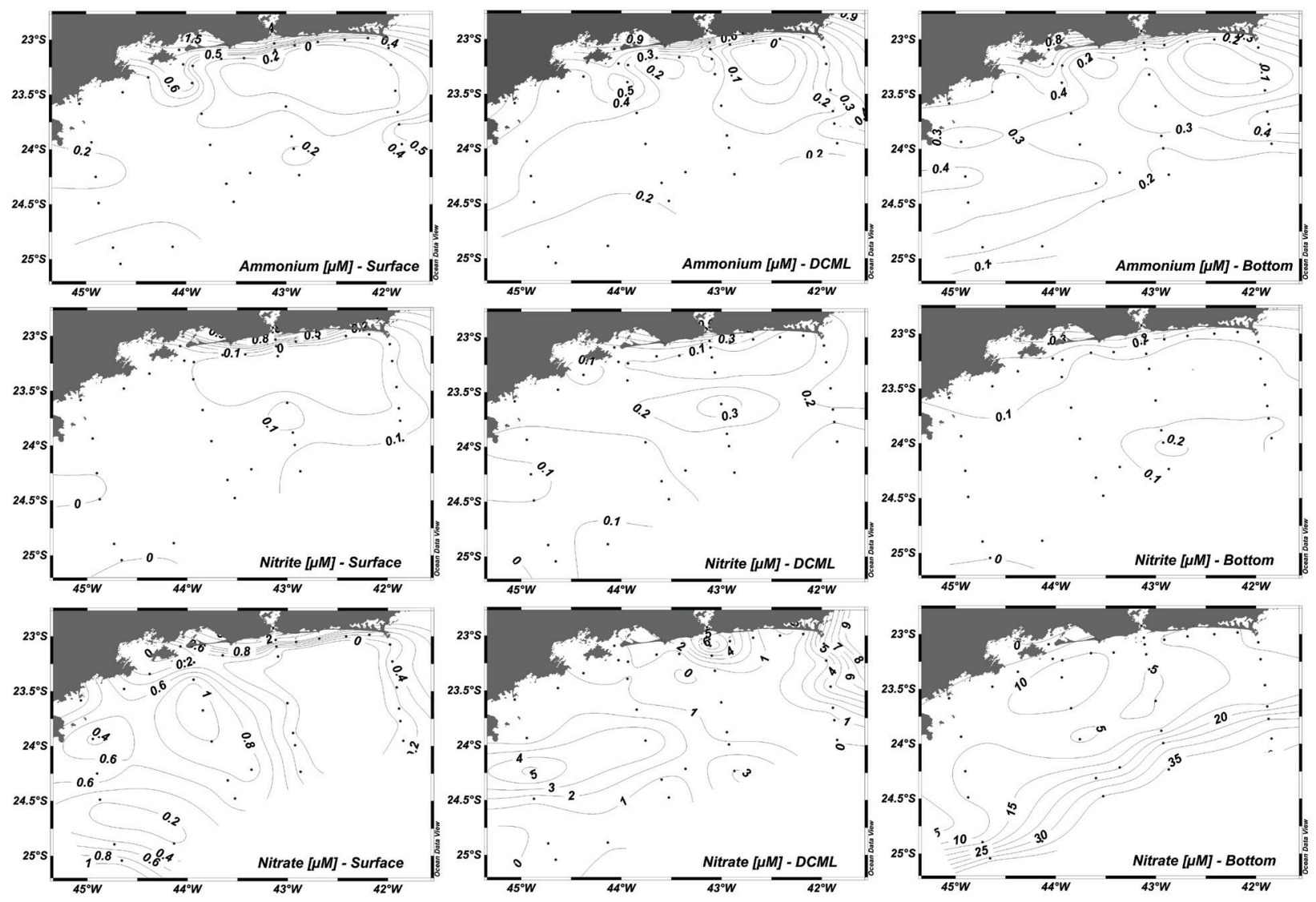

Figure 4: Surface plots of ammonium, nitrite and nitrate in Surface, DCM and Bottom.

continental slope (st. 22). Under the influence of GB plume phosphate concentration was $0.9 \mu \mathrm{M}$ (st. 14). In deep waters off SB concentrations varied between 1.6 $\mu \mathrm{M}$ (st. 16) to $1.1 \mu \mathrm{M}$ (st. 17). Near SSI, its maximum values were $0.9 \mu \mathrm{M}$ (st. 28), $1.6 \mu \mathrm{M}$ (st. 27) and 1.2 $\mu \mathrm{M}$ (st. 26), with relative constant concentrations from the DCM to the bottom.

Among the analyzed nutrients, silicate showed the highest amplitude of variation, from $0.6 \mu \mathrm{M}$ (st. 5) in the surface, to $51.1 \mu \mathrm{M}$ (st. 23) at $1249 \mathrm{~m}$ in the
AAIW domain (Fig. 5). At st. 14 (GB), silicate levels were $17 \mu \mathrm{M}$ at surface and $8.1 \mu \mathrm{M}$ at $17 \mathrm{~m}$ in the nearest station (st. 13). In SB (st. 15), the highest concentration was $5.7 \mu \mathrm{M}$ at $10 \mathrm{~m}$ depth. The deep cores off SB exhibited concentrations up to $7.4 \mu \mathrm{M}$ and $9.3 \mu \mathrm{M}$ in stations 16 and 17 , respectively, from the DCM to the bottom. Off SSI, silicate showed values between $7.1 \mu \mathrm{M}$ to $10.8 \mu \mathrm{M}$ (st. 28,27 and 26 ) along the water column, following the same pattern of nitrate and phosphate. 


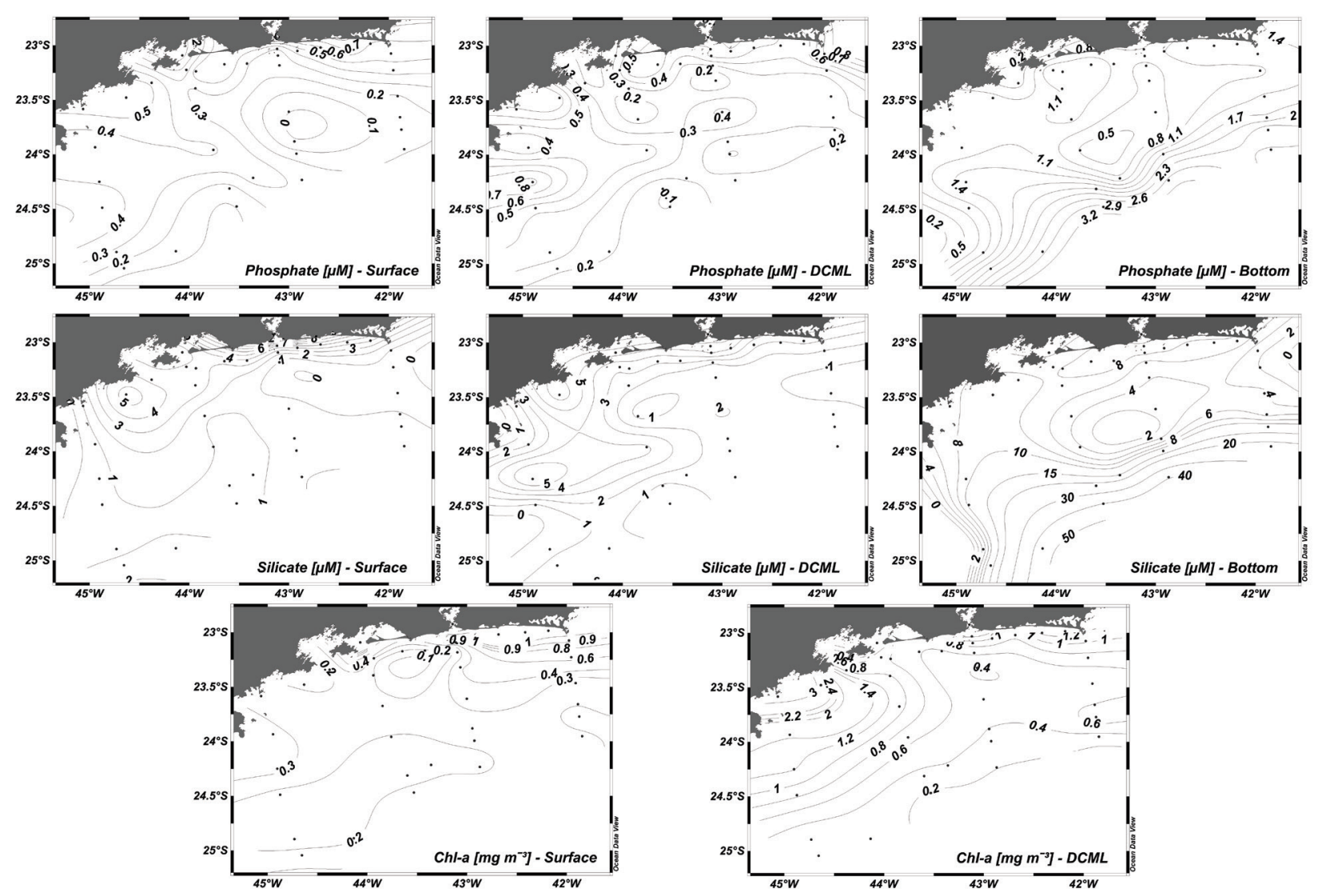

Figure 5: Surface plots of phosphate, silicate and N:P ratios in Surface, DCM and Bottom.

The N:P ratios in surface and in DCM were generally low in the entire study area, characterizing limitation of inorganic nitrogen (considered the sum of nitrate, nitrite and ammonium; Fig. 5). Although some exceptions occurred, in most cases both inorganic nitrogen and phosphorus species were at low concentrations. The $\mathrm{N}: \mathrm{P}$ ratio increases with depth, in the SACW and AAIW domain. Values higher than 15 were detected near the bottom.

Figure 6 presents the vertical distribution of nutrients in the transects in front of $G B$ and SB. Sepetiba Bay presented a lower contribution of DIN and phosphate and a moderate contribution of silicate.

\section{Chlorophyll-a}

Chlorophyll-a at surface ranged from $0.1 \mathrm{mg} \cdot \mathrm{m}^{-3}$ over the shelf break (st. 21) to $9.8 \mathrm{mg}^{-3} \mathrm{~m}^{-3}$ in GB (st. 14; Fig. 7). At SB a maximum of $1.8 \mathrm{mg} \cdot \mathrm{m}^{-3}$ was found at surface (St. 37). At stations 36, 37 and 38, in the coastline between GB and CF, chlorophyll-a presented surface values of $1.3 \mathrm{mg} \cdot \mathrm{m}^{-3}, 1.7 \mathrm{mg} \cdot \mathrm{m}^{-3}$ and $1.2 \mathrm{mg} \cdot \mathrm{m}^{-3}$, respectively. In the DCM, the western section of the study area showed in general higher concentrations, where the midshelf off SSI presented $1.4 \mathrm{mg} \cdot \mathrm{m}^{-3}$ (st. 28), $1.2 \mathrm{mg} \cdot \mathrm{m}^{-3}$ (st. 27) and $0.8 \mathrm{mg} \cdot \mathrm{m}^{-3}$ (st. 26) in the DCM. At the DCM in GB and SB, the concentrations of chorophyll-a were $1.5 \mathrm{mg} \cdot \mathrm{m}^{-3}$ and $1.2 \mathrm{mg} \cdot \mathrm{m}^{-3}$, respectively.

\section{Statistical Analysis}

The principal component analysis (PCA - Fig. 8) pointed out three groups of stations, with distinct environmental characteristics, that could be related to water masses distribution and estuarine plumes, considering either the neritic-oceanic or the depth gradients.

Considering the factorial plane resulting from the first two factors ( $72 \%$ of the total variation), the positive portion of factor $1(60 \%)$ was represented by the offshore stations, by waters under $200 \mathrm{~m}$ depth (GROUP 1), which presented higher concentrations of dissolved nutrients as well as low temperature, notably under the influence of AAIW and/or SACW, this last one also observed over the shelf. In the negative portion of factor 1, stations on the shelf and shelf break, mainly in surface waters (GROUP 2), were correlated to higher temperatures, corresponding to TW. Factor $2(12 \%)$ positive portion was composed by coastal stations (GROUP 3) located in the entrance of Guanabara and Sepetiba bays, dominated by CW. 


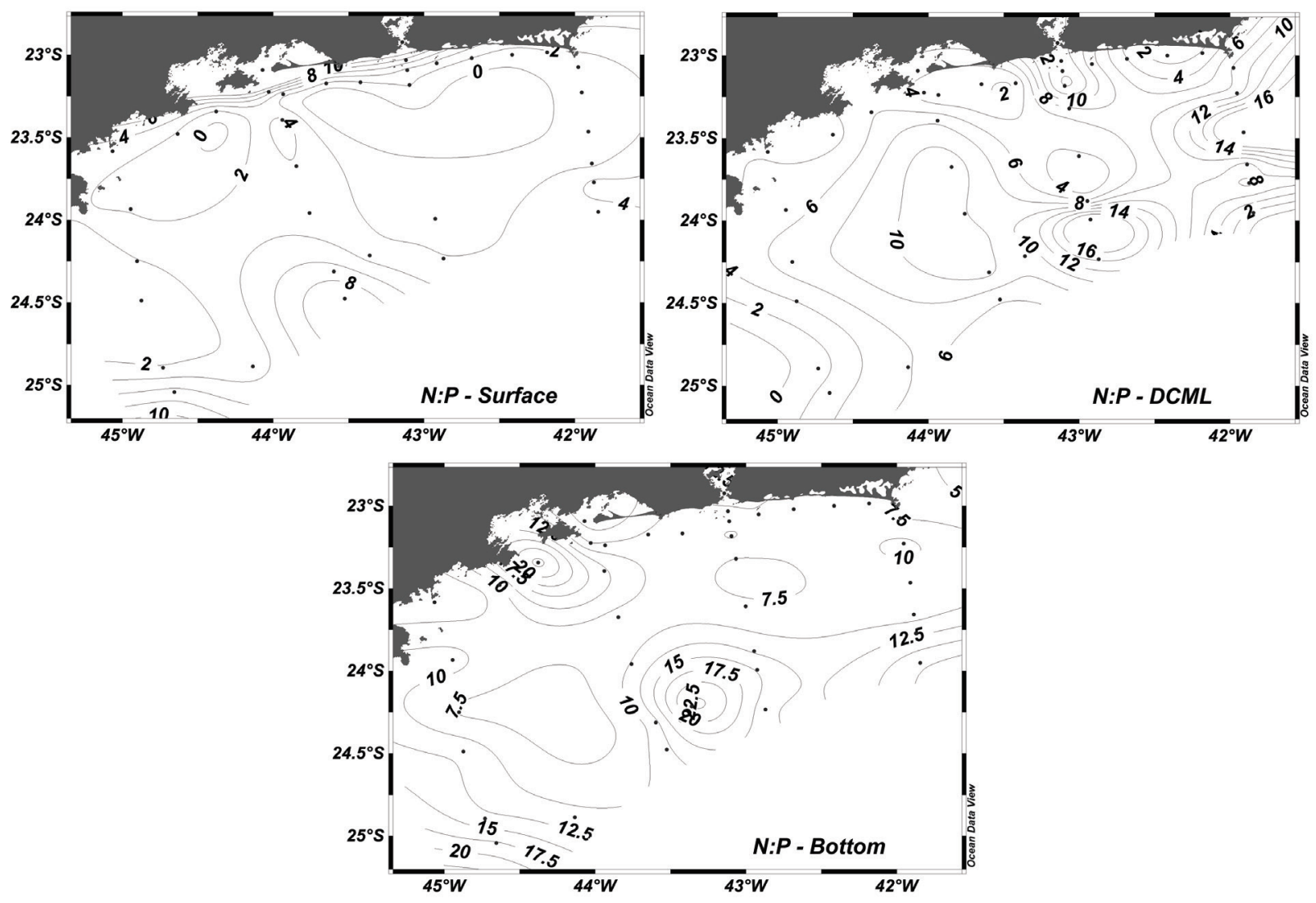

Figure 6: Vertical profiles of Dissolved Inorganic Nitrogen (DIN), Phosphate and Silicate in GB (left) and SB (right). The dotted line represents the $18^{\circ} \mathrm{C}$ isotherm. Station numbers depicted above the figures.

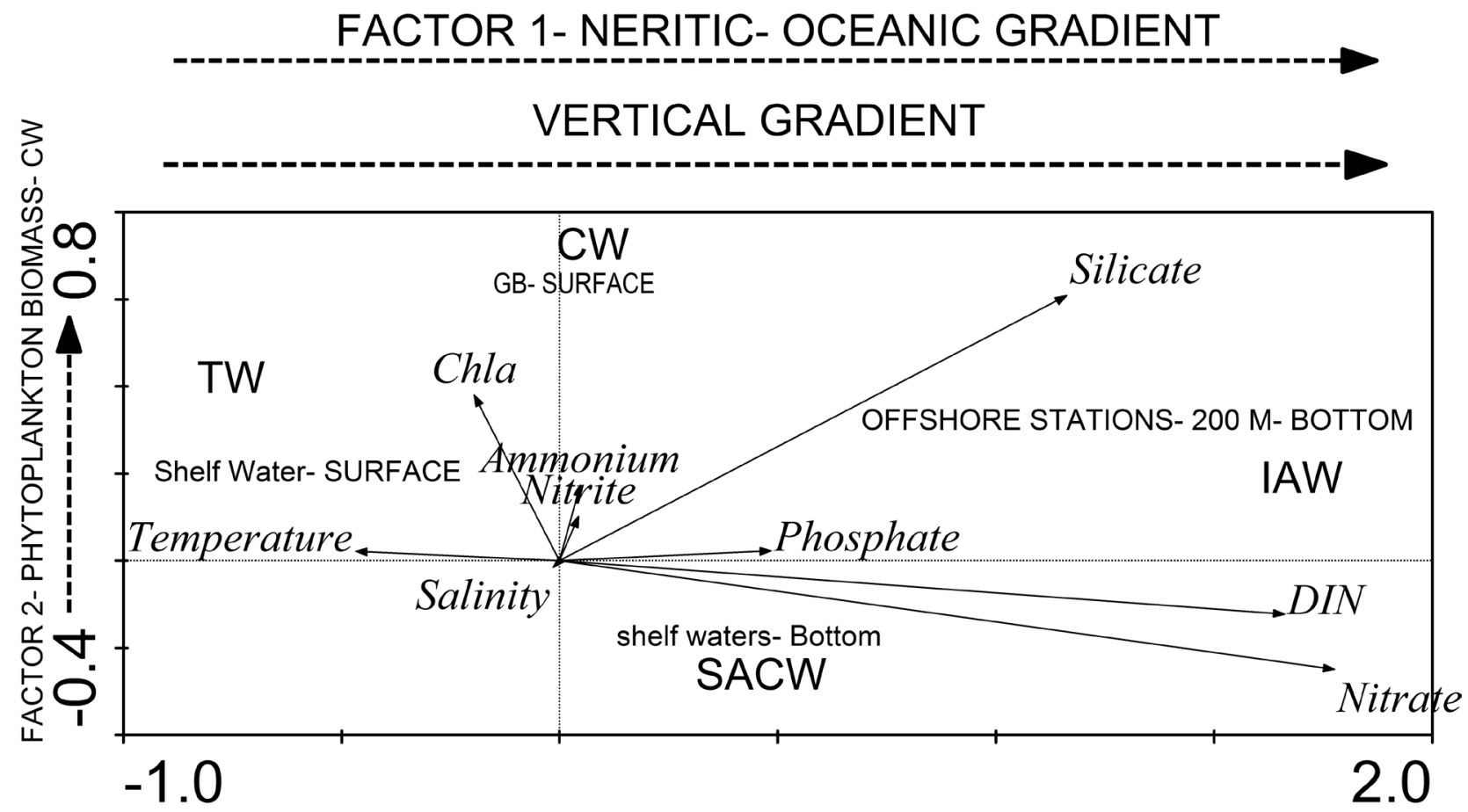

Figure 7: Principal component analysis of the temperature, salinity, nutrients and chlorophyll-a data. 

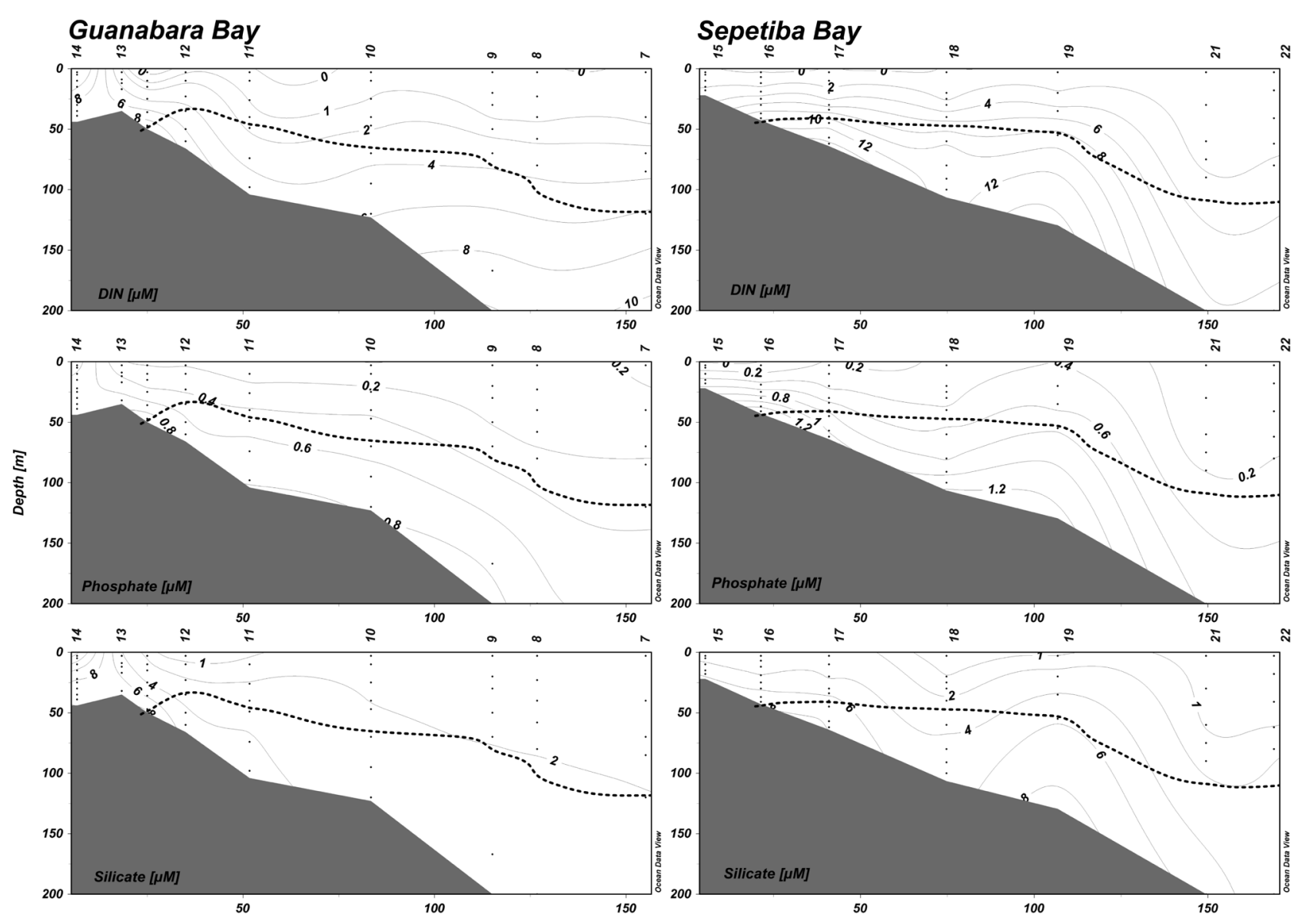

Figure 8: Surface plots of chlorophyll-a in Surface and DCM.

\section{DISCUSSION}

\section{Nutrient sources}

We state here the principal observed factors which were responsible for the introduction of new nutrients into the study area: local estuarine plumes, remote coastal waters intrusion from southernmost latitudes, SACW intrusion over the continental shelf and its aftermost bottom enrichment in nutrients due to resuspension of sediments and remineralization processes.

\section{Local Estuarine Plumes}

As expected, Guanabara Bay is an important source of new nutrients to the continental shelf of Rio de Janeiro. The lower salinities found in the western section of the study area suggests an increased influence of local and/or remote continental runoff, although it is difficult to distinguish both sources. Estuarine plumes may form a surface low-density layer, being the resultant water column stratification dependent on local turbulence. The destination of the plume is also dependent on many factors, such as the freshwater discharge, coastal morphology and hydrodynamics, wind regime, pressure gradient and Coriolis forces (Simpson, 1997). Two or more estuaries may form a line source of freshwater, creating a coastal low-salinity band (Kourafalou et al., 1996). By delineating the estuarine plumes with the salinity and nutrient values (Figs 3 and 6 ), the GB plume was detected up to $26 \mathrm{~km}$ off its estuarine mouth, while $\mathrm{SB}$ plume was seen up to $34 \mathrm{~km}$ from its mouth. This difference might be due to the freshwater discharge (ANA, 2013), but other factors such as tidal patterns should not be forgotten.

Both coastal bays have a long eutrophication history triggered by urban and industrial advances (Kjerfve et al., 1997; 2001; Ribeiro \& Kjerfve, 2001; Carreira et al., 2004; Cunha et al., 2006; Molisani et al., 2006), resulting in plumes with high concentrations of nutrients primarily due to organic matter oxidation. While GB has undergone an eutrophication process since the beginning of XIX century, SB has been impacted since the half of $X X$ century with a different pattern of land use, explaining its lower concentrations of nutrients. Biogeochemical processes associated to estuarine plumes have been studied in coastal eutrophication context (Lui \& Chen, 2012), and many 
were performed in the southern region of Brazil (e.g Ciotti et al., 1995; Schettini et al., 2005; Braga et al., 2008; Burrage et al., 2008; Möller Jr. et al., 2008).

\section{Remote coastal waters influence}

The dominance of waters with salinity below 35.5 on surface over the western section of the study area (Fig. 3) suggests the presence of waters of coastal origin as far as $106 \mathrm{~km}$ off SB and $107 \mathrm{~km}$ off UB. In the absence of a significant freshwater local source, remote coastal waters are most likely to have reached this region. Although their origins are unsure, a penetration of southernmost coastal waters into southern Brazilian coast is discussed in literature (e.g. Ciotti et al., 1995; Soares \& Möller Jr, 2001; Souza \& Robinson, 2004; Burrage et al., 2008; Möller Jr. et al., 2008; Marques et al., 2009). This region is characterized by high seasonal variability, such as shifts of BrazilMalvinas confluence zone (northernmost during austral winter), and the presence of coastal waters in inshore areas associated to the Plata River (Uruguay; Souza \& Robinson, 2004) and also to Lagoa dos Patos runoff (Rio Grande do Sul, Brazil; Burrage et al., 2008).

The wintertime wind regime contributes to the northern penetration of those coastal waters, and Stevenson et al. (1998) demonstrated that this influence may reach up to SB in southeast Brazil during this season of the year, as observed in the present study and show in figure 9. According to Stevenson et al. (1998), those coastal waters flow inshore and northward, in an opposite sense of the outer Brazil
Current, which flows mainly along the continental slope (Silveira et al., 2000). Along its path, the coastal waters gradually lose their original thermohaline and trophic conditions by heat and mass exchanges and biological activity, as well as by receiving contributions from estuarine sources.

The inner shelf circulation of north of São Paulo presents variations in sub-inertial scale, being commonly oriented in an opposite path of Brazil Current in austral winter due to atmospheric fronts as observed between June 19th and 22nd of 2010, prior to the oceanographic cruise (INMET, 2013). Additionally, in the south of SSI the isobaths of $20 \mathrm{~m}$ and $60 \mathrm{~m}$ converge (Castro et al., 2008), and the adjacent flow is quickly oriented to greater depths, surrounding the island and acquiring cyclonic relative vorticity in order to preserve its potential vorticity, as shown by the trend to rotation of the velocity vectors in surface waters (Fig. 9).

Velocity vectors at higher depths (data not shown) off SSI indicate a vertical shear with bottom currents oriented from east to west, according to the climatological flow of SACW in this area. The resulting turbulence might be responsible for the high levels of nutrients and chlorophyll-a in stations 26, 27 and 28 . Besides, this short scale process possibly advects coastal zone material west of SSI to midshelf waters, creating a frontal zone and enhancing primary productivity.

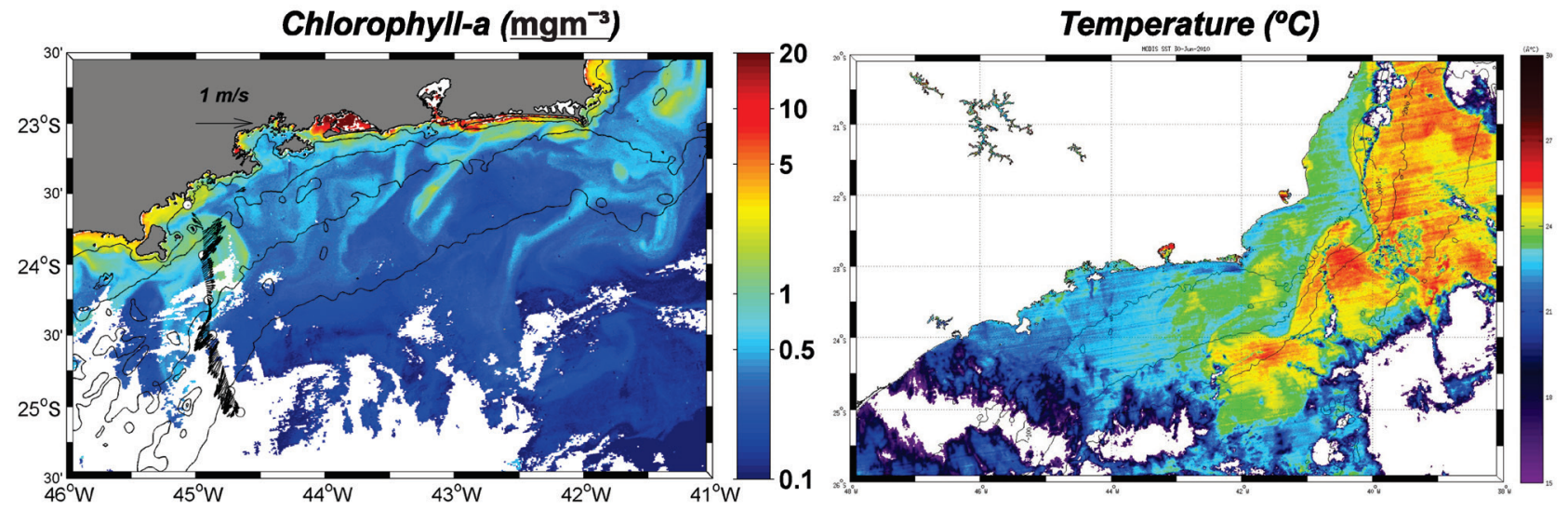

Figure 9: MODIS- TSM image 30/01/2012 showing a low temperatures nearby SSI transect. The black square depicts the area of SSI transect showing the velocity vectors computed for $21 \mathrm{~m}$ depth in the SSI transect superimposed to a MODIS- Chl-a image $30 / 01 / 2012$.

\section{SACW presence over the continental shelf}

The mechanisms involved in the SACW intrusion over the continental shelf of Brazil and the coastal upwelling off CF are well discussed in literature (Castro et al., 2005; 2006). In this region, intense gradients of coastline orientation and continental margin morphology are determinant to the Brazil Current meandering and the consequent intrusion of SACW over the continental shelf. The wind regime is more favorable to this process during summer, but it also occurs during other seasons. The width of the continental shelf in CF is the shortest in the study area (around $73 \mathrm{~km}$ ), and it gradually increases to the north of São Paulo (153 $\mathrm{km}$ off UB). This difference influenced the position of SACW in this study, closer to the coastal zone near CF and more distant off UB. 
Even when not present at surface, the SACW over the continental shelf has influence on primary producers biomass in DCM, but its nutritive potential is limited by light availability. The uptake of nutrients by primary producers adapted to low light conditions reduces its trophic potential, and when SACW reach the upper layers of the water column it can be as depleted in nutrients as TW and CW (Aidar et al., 1993).

\section{SACW bottom enrichment in nutrients (regeneration processes)}

In the range from 21 to $75 \mathrm{~km}$ from SB mouth, high concentrations of nitrate, phosphate and silicate were detected near the bottom, in the SACW domain (Fig. 8). Although SACW is recognized as a water mass with elevated trophic potential, the values presented here were higher than those of surrounding regions, in similar depths. The same occurred mainly for phosphate in Guanabara Bay, between $52 \mathrm{~km}$ and $151 \mathrm{~km}$ from coastline (st. 9, 10 and 11).

This enrichment in nutrients may occur after the intrusion of SACW over the continental shelf and was described for Ubatuba (Aidar et al., 1993; Braga \& Müller, 1998) and southern Brazil (Braga et al., 2008). In coastal regions, turbulence generating processes, such as tidal currents, may resuspend bottom sediments and make organic matter available for regeneration in the water column (Aidar et al., 1993). Along its path through the continental shelf, SACW shows local depletions in dissolved oxygen due to regeneration processes by the contact with the bottom (Braga et al., 2008). Braga \& Müller (1998) suggests that the enrichment in phosphate is higher than in nitrate because of losses by denitrification.

\section{Regionalization of Rio de Janeiro and north of São Paulo continental margin}

The study area comprises two biogeographical regions defined by Gonzalez-Silveira et al. (2004): "Cabo Frio upwelling region ( $\left.23^{\circ} \mathrm{S}\right)$ " and "Continental

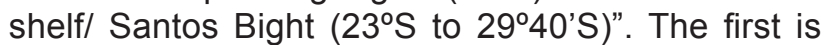
characterized by the coastal upwelling and its chemical and biological effects, while the second is notable by its wide continental shelf and the meandering pattern of Brazil Current, as well as the presence of low-salinity waters in the inner shelf.

The present dataset demonstrates some differences between those regions, such as the dominance of surface waters with salinities below 35.5 at the western part of the study area and a greater penetration of SACW coastwards in the eastern portion. It is possible to define by the data obtained in this oceanographic cruise a transition zone between the two biogeographical regions described, marked by the continental runoff from GB and SB. According to Castro et al. (2006), this region may also receive remote upwelling plumes from Cabo Frio.

Based on recent sedimentation processes, Mahiques et al. (2004) highlighted the importance of SSI in the hydrodynamics of northern São Paulo, which may act as a boundary between different physical oceanographic regimes westwards and eastwards from the island.

\section{CONCLUSIONS}

The continental margin of Rio de Janeiro presented in the winter of 2010 generally low concentrations of nutrients in the upper layers of the water column, with some exceptions: the coastal zone influenced by local estuarine plumes (GB and SB), which importance was highlighted by the principal components analysis; areas where the SACW was present on the base of the mixed layer; off SSI due to the short scale oceanographic process and vertical and horizontal shear of currents with an inshore northwards flow; and off SB in the midshelf due to regeneration processes from the bottom up to the DCM. Under a biogeographic point of view, the study area corresponded to a transition zone between two distinct biogeographic regions described in the literature, with some unique aspects as listed above. More observations in different seasons are important to the better understanding of the oceanographic patterns of the area.

\section{ACKNOWLEDGEMENTS}

This research was supported by MCT (Ministério da Ciência e Tecnologia) in cooperation with the Brazilian Navy who made available specialized personnel and equipments. The authors are grateful to Dr. Josefa Varela Guerra, chief scientist of the oceanographic cruise, Dr. Áurea Maria Ciotti of CEBIMAR-USP for chlorophyll-a analysis, Elaine Aparecida de Oliveira (PPG OCN-UERJ) for satellite images acquisition and processing, and Roberto Freires de Oliveira (LABOGEO-UERJ) for ADCP data processing. American Journal Experts (AJE) revised this manuscript.

\section{REFERENCE}

Agência Nacional de Águas, Brazil. Last access: January 25, 2013. Available in: http://hidroweb. ana.gov.br

Aidar, E.; Gaeta, S.A.; Gianesella-Galvão, S.M.F.; Kutner, M.B.B. \& Teixeira, C. 1993. Ecossistema 
costeiro subtropical: nutrientes dissolvidos, fitoplâncton e clorofila-a e suas relações com as condições oceanográficas na região de Ubatuba, SP. Publicação especial Inst. Oceanográfico 10, 9-43.

Aminot, A. \& Chaussepied, M. 1983. Manuel des analyses chimiques en milieu marin. Brest,CNEXO. 379p.

Arndt, S.; Lacroix, G.; Gypens, N.; Regnier, P. \& Lancelot, C. 2011. Nutrient dynamics and phytoplankton development along an estuarycoastal zone continuum: A model study. Journal of Marine Systems, Volume 84, Issues 3-4, Pages 49-66.

Braga, E.S. \& Müller, T.J. 1998. Observation of regeneration of nitrate, phosphate and silicate during upwelling off Ubatuba, Brazil, $23^{\circ} \mathrm{S}$. Continental Shelf Research 18, 915-922.

Braga, E. S. \& Niencheski , L. F. H. 2006. Composição das massas de água e seus potenciais produtivos na área entre o Cabo São Tomé (RJ) e o Chuí (RS). In: O ambiente oceanográfico da plataforma continental e do talude na região sudeste-sul do brasil. 1 ed. São Paulo: EDUSP. Cap. 3, p. 161-218.

Braga, E.S.; Chiozzini V.C.; Berbel G.B.B.; Maluf J.C.C.; Aguiar V.M.C.; Charo M.; Molina D.; Romero S.I. \& Eichler B.B. 2008. Nutrient distributions over the Southwestern South Atlantic continental shelf from Mar del Plata (Argentina) to Itajaí (Brazil): Winter-summer aspects. Continental Shelf Research 28, 1649-1661.

Burrage, D.; Wesson, J.; Martinez, C.; Pérez, T.; Möller Jr., O. \& Piola, A. 2008. Patos Lagoon outflow within the Rio de la Plata plume using an airborne salinity mapper: Observing an embedded plume. Continental Shelf Research 28, 1625-1638.

Carreira, R.S.; Wagener, A. L.R. \& Readman, J.W. 2004. Sterols as markers of sewage contamination in a tropical urban estuary (Guanabara Bay, Brazil): space-time variations. Estuarine Coastal and Shelf Science. 60, 587-598.

Castro, B.M.; Brandini, F. P.; Pires-Vanin, A. M. S. \& Miranda, L. B. 2005. Multidisciplinary oceanographic processes on the Western Atlantic Continental Shelf located between $4^{\circ} \mathrm{N}$ and $34 \mathrm{~S}$, in: Robinson, A.R., Brink, K.H. (Eds.), The Sea. John Wiley \& Sons, New York. v. 14, pp. 259-293.

Castro, B. M.; Lorenzzetti, J. A.; Silveira, I. C. A. \& Miranda, L. B. 2006. Estrutura termohalina e circulação na região entre o Cabo São Tomé (RJ) e o Chuí (RS). In: O ambiente oceanográfico da plataforma continental e do talude na região sudeste-sul do Brasil. 1 ed. São Paulo: Ed. USP. Cap. 1, p. 11-120. 466 p.
Castro, B.M.; Miranda, L.B.; Silva, L.S.; Fontes, R.F.C.; Pereira, A.F. \& Coelho, A.L. 2008. Processos Físicos: Hidrografia, Circulação e Transporte, in: Pires-Vanin, A.M.S. (Org.), Oceanografia de um Ecossistema Subtropical: Plataforma de São Sebastião, SP. Editora da Universidade de São Paulo, São Paulo. pp. 59-121.

Ciotti, A.M.; Odebrecht, C.; Fillmann, G. \& Möller Jr., O.O. 1995. Freshwater outflow and Subtropical Convergence influence on phytoplankton biomass on the southern Brazilian continental shelf. Continental Shelf Research, Vol. 15, No. 14, pp $1737-1756$.

Codas - Common Ocean Data Access System. University of Hawaii (USA). Last access: January 24, 2013. Available in: http://currents.soest.hawaii. edu/docs/adcp doc/index

Coelho, A. L. 2010. Intrusão da ACAS na região costeira adjacente à Baía de Sepetiba. Revista Anual da Diretoria de Hidrografia e Navegação. TOMO LXVII, 119-116.

Conkright, M. E; Greg, W. W. \& Levitus; S. 2000. Seasonal cycle of phosphate in the open ocean. Deep-Sea Research I, v. 47, p. 159-175.

Cunha, C. L. N.; Rosman, P. C. C.; Ferreira, A. P. \& Monteiro, T. C. N. 2006. Hydrodynamics and water quality models applied to Sepetiba Bay. Continental Shelf Research. 26, 1940-1953

Gonzalez-Silveira, A.; Santamaria-Del-Angel, E.; Garcia, V.M.T.; Garcia, C.A.E.; Millán-Nunez, R. \& Muller-Karger, F. 2004. Biogeographical regions of the tropical and subtropical Atlantic Ocean off South America: classification based on pigment (CZCS) and chlorophyll-a (SeaWiFS) variability. Continental Shelf Research 24(9), 983-1000.

Instituto Nacional de Meteorologia, Brazil. Last acess: January 20, 2013. Available in: http://www.inmet. gov.br/portal/

Kjerfve, B.; Lacerda, L.D. \& Dias, G.T.M. 2001. Baía de Guanabara, Rio de Janeiro, Brazil, in: Seeliger, U. , Kjerfve, B. (Eds.), Coastal Marine Ecosystems of Latin America. Springer-Verlag, Berlin, Heidelberg. pp. 107-117.

Kjerfve, B.; Ribeiro, C.H.A.; Dias, G.T.M.; Filippo, A. M. \& Quaresma, V. S. 1997. Oceanographic Characteristics of an Impacted Coastal Bay: Baía de Guanabara, Rio de Janeiro, Brazil. Continental Shelf Research 17(13), 1-13.

Kourafalou, V.; Oey, L.; Wang, J. \& Lee, T. 1996. The fate of river discharge on the continental shelf 1. Modeling the river plume and the inner shelf coastal current. Journal of Geophysical Research 101(C2), 3415-3434.

Lui, H.K. \& Chen, C.T.A. 2012. The nonlinear relationship between nutrient ratios and salinity 
in estuarine ecosystems: implications for management. Current Opinion in Environmental Sustainability 4(2), 227-232.

Mahiques, M.M., Tessler, M.G., Ciotti, A.M., Silveira, I.C.A., Sousa, S.H.M., Figueira, R.C.L., Tassinari, C.C.G., Furtado, V.V., Passos, R.F. 2004. Hydrodynamically driven patterns of recent sedimentation in the shelf and upper slope off Southeast Brazil. Continental Shelf Research 24, 1685-1697.

Marques, W. C.; Fernandes, E. H.; Monteiro, I. O.; Möller, O. O. 2009. Numerical modeling of the Patos Lagoon coastal plume, Brazil. Continental Shelf Research 29(2009) 556-571.

Molisani, M.M.; Kjerfve, B.; Lacerda, L.D. 2006. Water discharge and sediment load to Sepetiba Bay from an anthropogenically-altered drainage basin, SE Brazil. Journal of Hydrology 331, 425-433.

Möller Jr., O.O.; Piola, A.R.; Freitas, A.C. \& Campos, E.J.D. 2008. The effects of river discharge and seasonal winds on the shelf off southeastern South America. Continental Shelf Research 28, 1607- 1624.

Nittrouer, C.A. 1993. Controlling the ingredients that flow to the sea. Oceanus, 36: 12-18.

Pereira, M.D.; Schettini, C.A.F. \& Omachi, C.Y. 2009. Caracterização de feições oceanográficas na plataforma de Santa Catarina através de imagens orbitais. Revista Brasileira de Geofísica, 27(1):81-93.

Ribeiro, C. H. A., Kjerfve, B. 2002. Anthropogenic influence on the water quality in Guanabara Bay, Rio de Janeiro, Brazil. Reg. Environ. Change 3, 13-19

Schettini, C.A.F.; Resgalla JR., C.; Pereira Filho, J.; Silva, M.A.C.; Truccolo, E.C. \& Rörig, L.R. 2005. Variabilidade temporal das características oceanográficas e ecológicas da região de influência fluvial do Rio Itajaí-Açu. Braz. J. Aquat. Sci. Technol., 9(2):93-102.
Schlitzer, R. 2011. Ocean Data View. Available in: <http://www.awi-bremerhaven.de/GEO/ODV>.

Silva, L.C.F.; Albuquerque, C.A.M.; Cavalheiro, W.W. \& Hansen, C.M.P. 1984. Gabarito tentativo para as massas de água da costa sudeste brasileira. Anais Hidrográficos 51, 261-299.

Silveira, I. C. A.; Schmidt, A. C. K.; Campos, E. J. D.; Godoi, S. S. \& Ikeda, Y. 2000. A Corrente do Brasil ao Largo da Costa Leste Brasileira. Rev. bras. oceanogr. v. 48, n. 2, p.171-183.Simpson, J.H. 1997. Physical processes in the ROFI regime. Journal of Marine Systems. 12, 3-15.

Soares, I. \& Möller Jr., O. 2001. Low-frequency currents and water mass spatial distribution on the southern Brazilian shelf. Continental Shelf Research (21):1785-1814.

Soares, M.G. 2005. Efeito de fontes distintas de eutrofização, antrópica e natural, na estrutura de tamanho do fitoplâncton e na relação entre a produção primária e bacteriana: estudos na Baía de Guanabara e na região de ressurgência de Cabo Frio, RJ. Tese de doutorado. Instituto Oceanográfico - USP. 208p.

Souza, R. B. \& Robinson, I. S. 2004. Lagrangian and satellite observations of the Brazilian Coastal Current. Continental Shelf Research, v. 24, p. 241-262.

Stevenson, M. R.; Dias-Brito, D; Stech, J. L. \& Kampel, M. 1998. How do cold water biota arrive in a tropical bay near Rio de Janeiro, Brazil? Continental Shelf Research, v.18, p. 1595-1612.

Welschmeyer, N.A. 1994. Fluorometric analysis of chlorophyll $a$ in the presence of chlorophyll $b$ and pheopigments. Limnology and Oceanography: 39, 1985-1992. 